\title{
Article \\ Personal and Social Consequences of Psychotropic Substance Use: A Population-Based Internet Survey
}

\author{
María Luisa Ballestar-Tarín ${ }^{1}$, Vanessa Ibáñez-del-Valle ${ }^{1,2}$, Omar Cauli $^{1,2, *(D)}$ and Rut Navarro-Martínez ${ }^{1,2}$ \\ 1 Department of Nursing, Faculty of Nursing and Podiatry, University of Valencia, Avda Menéndez Pidal 19, \\ 46010 Valencia, Spain; M.luisa.ballestar@uv.es (M.L.B.-T.); Maria.V.Ibanez@uv.es (V.I.-d.-V.); \\ Rut.Navarro@uv.es (R.N.-M.) \\ 2 Frailty and Cognitive Impairment Organized Group (FROG), Department of Nursing, University of Valencia, \\ Avda Menéndez Pidal 19, 46010 Valencia, Spain \\ * Correspondence: Omar.Cauli@uv.es
}

Citation: Ballestar-Tarín, M.L.; Ibáñez-del-Valle, V.; Cauli, O.; Navarro-Martínez, R. Personal and Social Consequences of Psychotropic Substance Use: A Population-Based Internet Survey. Medicina 2022, 58, 65. https://doi.org/10.3390/medicina 58010065

Academic Editor: Mirko Manchia

Received: 1 November 2021

Accepted: 28 December 2021

Published: 1 January 2022

Publisher's Note: MDPI stays neutral with regard to jurisdictional claims in published maps and institutional affiliations.

Copyright: (C) 2022 by the authors. Licensee MDPI, Basel, Switzerland. This article is an open access article distributed under the terms and conditions of the Creative Commons Attribution (CC BY) license (https:// creativecommons.org/licenses/by/ $4.0 /)$.

\begin{abstract}
Background and objectives: Drug abuse has become a major worldwide health concern among all age groups. The present study analyses substance misuse and its social and personal consequences using a population-based internet survey in Spain. Materials and Methods: Screening for drug abuse (of alcohol, marijuana/hashish and psychostimulants) and its related risks and problems was performed using the Car, Relax, Alone, Forget, Friends, Trouble (CRAFFT) score. Socio-demographic factors, depressive, anxiety and stress symptoms as well as health habits were also evaluated. We used Linear regression methods to compare each variable's individual contribution so as to determine which one best explains the results. Results: In this population-based study, 1224 people completed and returned the online survey. Of all participants, 57\% reported consuming at least one substance based on the CRAFFT scale. While increasing age reduces the probability of personal and social consequences of consumption, people who smoke receive up to three times more $(\mathrm{OR}=3.370)$ recommendations from family and friends to reduce their consumption. As for the type of substance, the consumption of marijuana increases the risk of forgetting $(\mathrm{OR}=2.33)$ and the consumption of other psychostimulant substances almost triples the risk of consuming alone $(\mathrm{OR}=2.965)$. Combining substances can increase the rate of driving a vehicle after consumption by 3.4 times. Conclusions: Although age, smoking and the type of substances used increase the risk of suffering from social and personal consequences of the use or abuse of substances, future studies are needed to determine the influence of new variables as a potential tool for treating and minimizing the adverse consequences of drug abuse.
\end{abstract}

Keywords: CRAFFT scale; alcohol; marijuana; consumption; substance; social consequences

\section{Introduction}

Several studies show that experimentation with the effects of tobacco, alcohol and, to a lesser extent, other illegal substances begins during adolescence. Indeed, in recent decades, health agencies and university authorities have expressed concern about an increase in the use of alcohol and other substance abuse, e.g., of cannabis and amphetamines, among college students [1-9]. The abuse of these substances has become a major health concern worldwide, and although some adolescents who use or abuse these substances tend to reduce their consumption over time [10], it is plausible that a proportion of the adult population continues to use and abuse these substances. Several studies indicate that there is currently a relatively high risk of adults and/or older people maintaining problems with alcohol use, which can be combined with the use of other types of drugs [11-14], increasing the psychological, physical, economic [15] and social consequences [16]. Around $27 \%$ of Europeans aged 55 years and older report consuming alcohol on a daily basis. In addition, young people today drink more alcohol than previous generations, and it is to be anticipated that they will continue to do so as they age, leading to a higher prevalence 
of abuse of these substances in our elders of the future. Although the prevalence of illicit substances is higher among young people, there is an increase in the number of older adults who use them. Most older users of illicit substances are survivors because they begin this practice at an early age, and as with alcohol, are expected to continue their use into old age. In the United States, it has been estimated that up to $300 \%$ more older adults may use them by 2020 as a result of improvements in treatment and a declining overdose-related mortality rate $[17,18]$. In addition, the greater availability of these substances today is expected to accelerate their increased use among older users. At the same time, the use of substances such as marijuana is now so normalized that together with their relaxing and therapeutic effects, the growth in their use is understandable. There are multiple factors that contribute to the excessive consumption of alcohol [19-21], cannabis/marijuana, cocaine and tobacco, but in particular, they include the risk of presenting substance abuse behaviors due to changes in lifestyle [22], reduced socio-familial support [23-25] and the presence of stressful situations [26]. The consequences of alcohol misuse include physical health problems and poor academic performance $[27,28]$. For example, the health consequences of the abuse of alcohol, cannabis products and psychostimulants include alterations in the cardiocirculatory system [29-31], leading to tachycardia, whereby individuals with hypertension or heart failure may suffer worsening symptomatology. There are data indicating that there could be an increase in the incidence of anxiety crises, depression and psychosis due to chronic consumption of these substances among the many effects described on people's health [32,33]. However, there is relatively little research that analyzes the relationship between substance use and the personal and social consequences of that use.

For example, among the social consequences, there is increasing data showing the detrimental effect of cannabis use associated with driving, especially when combined with alcohol, which increases the risk of accidents [34-36] and intimate partner violence [37]. Personal problems due to substance abuse include family [38], relational [39] and psychological [40] problems, and the loss of friendships and even jobs [41]. Moreover, these effects are quite frequent and independent of the type of drug used [42,43]. The CRAFFT Screening Test is a short and widely used clinical assessment tool designed to screen for substance-related risks and problems. The acronym stands for the key words of the six items "Car, Relax, Alone, Forget, Friends, Trouble" related to the most common (personal and social) problems related the consumption of such substances [44]. Among them, they are common social problems associated to the abuse such the concerns of family and friends (question Friends) or getting into trouble with other persons (Trouble) due to drug abuse. The items Relax, Alone and Forget are referred to the consequences of drug abuse on behavior to maintain the intake despite the individuals observed the need to improve the psychological well-being (Relax), the need to experience the effects of the drugs when being alone (Alone) despite the intake of this drugs could alter personal ability to manage the own daily life issues (Forget). The consumption of drug abuse to relax or feel better (Relax) is based on the fact that auto-referred stress is a well-known risk factor in the development of addiction and in addiction relapse vulnerability $[45,46]$. Given an impaired ability to stop or control intake, many individuals abusing these drugs find themselves drinking alone (Alone) and consuming them while being alone represents an important issue for development of addiction [9,47-49]. In fact, many people experienced first the effects of substances of abuse with other individuals and then, with or without company. Drug abuse is a serious factor in memory loss (Forget) and a lack of concentration, which can alter several aspects of daily life. The Car question represents a safety risk screener [50]. Internet-based survey studies are a useful tool for collecting information on drug-use patterns [50-53], they are quick and cheap to prepare, and can reach a large number of people who use drugs directly, i.e., it is a means of analysis that can provide a detailed and realistic picture of drug use and its personal and social consequences [54-57]

In this study, we had both descriptive and analytical objectives. The first, descriptive, was to estimate drug abuse prevalence and its social and personal consequences based on CFRATT screening tool in the Spanish population, based on internet-based survey. 
The second, analytical objective was based on the hypothesis that there are some sociodemographic factor influencing the use of these substances and the social and personal consequences (CRAFFT) associated with them. The following objectives were of the study:

Examine the use of alcohol, tobacco, marijuana/hashish and other illicit drugs.

Explore the social and personal consequences of substance abuse and the moderating effect of sociodemographic variables.

Study whether there is a relationship between this use and psychological factors such as stress, anxiety and depression.

\section{Materials and Methods}

\subsection{Study Design and Population}

This cross-sectional survey was conducted between November 2020 and February 2021. Exclusion criteria included being under 18 years of age and refusal to participate. Calculating the proportion of an infinite population with a precision of $\pm 3 \%$, and for a confidence level of $95 \%$, a sample size of 1099 subjects was estimated. We increased this figure to 1224 subjects $(10 \%)$ in anticipation of possible losses because the nature of the study of "drug abuse" means there could be losses, even if it is conducted anonymously for all participants. The calculation was performed with the Epi Info statistical package version 7.2. For the calculation of the sample size, an infinite population was considered. A population is considered infinite when the total number of observation units is unknown or the population is greater than 10,000 [58,59]. According to data from the National Institute of Statistics, in 2020 the Spanish population over 18 years of age was 39,180,773 [60].

\subsection{Data Collection}

Data were collected electronically using a self-administered questionnaire specifically designed for this study using Google Forms. The participants were recruited between November 2020 and February 2021. During this period, the questionnaire was launched via Facebook, Twitter and Instagram, which are the most globally popular social networks. For wider distribution of the survey, the survey link was subsequently sent via email through the researchers' contact lists. Likewise, the survey was not scheduled to close when a sufficient number of people surveyed was obtained according to age or gender criteria. To know the time required to complete the online questionnaire, all members of the research team prior to its launch, filled out the survey and the time spent ranged between 8-12 min. The survey participants received no incentives.

The questionnaire gathered sociodemographic, lifestyle, and clinical data. The sociodemographic variables included age, gender, nationality, marital status and/or the existence of a stable partner, housing situation, and primary employment status. Regarding lifestyle, we asked about consumption and frequency of stimulant drinks (coffee, tea or cola), smoking, regular physical activity ( 30 min per day, 5 or more days per week) and sedentary periods of more than $2 \mathrm{~h}$ per day. In addition to indicating their weight $(\mathrm{kg})$ and height $(\mathrm{cm})$ for the calculation of BMI, the participants were asked to state whether they suffered from a chronic disease and if so, which one, as well as their self-perception of their overall state of health, using a scale of 1-10, where a higher score indicated a better self-perception of their health status. The participants also completed a package of validated self-assessment instruments on sleep quality, stress level, mood and substance abuse, as explained below.

\subsection{Assessment of Substance Abuse}

When assessing substance abuse (alcohol, cannabis and other illicit drugs, including illegal, over-the-counter and prescription drugs) and its consequences, we used the CRAFFT scale developed by Knight et al. [44] which has been validated in the Spanish language [61]. This scale is a brief, self-administered psychometric instrument designed to briefly and effectively identify individuals at risk for substance abuse. The CRAFFT questionnaire, with nine dichotomous response items (YES or NO), is divided into two parts. The first part, or part A, includes three questions on the use of alcohol, marijuana/hashish and other illicit 
drugs in the past 12 months. The second part, or part B, consists of six questions assessing problems related to the use of these substances. If the answers to the three questions in part $\mathrm{A}$ are "NO", the respondent only answers the first question in part $\mathrm{B}$ of the questionnaire. However, if "YES" is answered to any of the three items in part A, the respondent must complete the entirety of part $B$ of the questionnaire. The scores for each of these items ranged from $0(\mathrm{NO})$ to 1 point (YES). The total score of the scale is obtained from adding the scores for the six items in part B. Scores equal to or higher than 2 points suggest abusive consumption, indicating the need for further assessment.

\subsection{Self-Perceived Stress Level}

Perceived stress was assessed using Cohen's Perceived Stress Scale (PSS) [62] which has been validated in Spanish language [63]. The PSS is the best known instrument for measuring perceived psychological stress, i.e., the extent to which everyday life situations are appraised as stressful. This scale is composed of ten items used to assess how often the respondent feels a certain way during the last month. The responses are scored 0 (never), 1 (almost never), 2 (sometimes), 3 (quite often) or 4 (very often). However, items 4, 5, 7 and 8 are scored in reverse or inverted form. The total score ranges from 0 to 40 points, with higher scores indicating a higher degree of perceived stress.

\subsection{Depressive and Anxiety Symptoms}

We used the Goldberg Anxiety and Depression Scale to assess the level of anxiety or depression [64] which has been validated in Spanish language [65]. This is a questionnaire that not only orients the diagnosis towards anxiety or depression (or both in mixed cases), but also discriminates between them and quantifies their respective intensities. This scale consists of two subscales-one for anxiety and the other for depression. Each of the subscales is composed of nine dichotomous response items (YES or NO) to determine whether the respondent has had any of the symptoms mentioned in the last two weeks. The cut-off points are four or more points or affirmative answers for the anxiety scale, and two or more for the depression scale. The higher the score, the more severe the problem (the maximum possible score is 9 points for each of the subscales).

\subsection{Ethical Considerations}

This project was approved by the Human Research Ethics Committee of the University of Valencia (Valencia, Spain) (procedure number 1,232,539, dated 21 May 2020). Before participants could access the data collection instrument itself, they were provided with information about the study and had to explicitly express their wish to participate. Confidentiality and anonymity of the data were maintained through the online survey setup.

\subsection{Statistical Analysis}

A descriptive analysis of the sociodemographic variables was performed, showing the distribution of percentages for the qualitative variables, and the mean and standard deviation for quantitative variables. Non-compliance with normality was checked using the Kolmogorov-Smirnov test. The Mann-Whitney U and Kruskal-Wallis tests were used to compare means between the quantitative variables, and the Chi-square test for the comparison of proportions. Fisher's exact test was used for comparisons in two-by-two tables. Spearman's linear correlation coefficient was used to establish the correlation between the variables studied.

Logistic regressions were used to try to make a predictive model of consumption and the consequences of consumption. Logistic regression can be used to evaluate several factors simultaneously that are presumably related in some way (or not) to the dependent variable. Logistic regression analysis makes it possible to obtain measures of association (odds ratio) for each variable adjusted for the others and to detect possible interactions between them and the effect studied. First, logistic regression was performed to determine which sociodemographic and lifestyle variables are related to consumption, and how 
the variables that are associated with consumption are related to the consequences of consumption (CRAFFT-B items). Several regression analyses were carried out, the first to determine the variables that influence the consumption or not of substances. Subsequently, six logistic regression analyses were carried out, one for each of the items that constitute part B of the CRAFFT questionnaire, related to the consequences of consumption. These items (B1, B2, B3, B4, B5, B6) are dichotomous variables $(0=$ No and $1=$ Yes $)$. It is not done with the overall CRAFFT score. The interactions between independent variables are of concern, but the authors did not address this issue.

The level of statistical significance was established at $p$ values below 0.05 . The analysis was performed with SPSS 26 statistical software (IBM Corp, Armonk, NY, USA) licensed by the University of Valencia.

\section{Results}

\subsection{Description of the Sample}

The sample consists of 1224 participants who completed an online survey during the period from November 2020 to February 2021. The sociodemographic, lifestyle and substance use characteristics of the sample are presented in Tables 1 and 2. A total of 192 men $(15.7 \%)$ and 1031 women $(84.3 \%)$ participated, with a mean age of $33.61( \pm 13.03)$. The marital status was: $51.9 \%$ single; $42 \%$ married/cohabiting with a partner; $5 \%$ divorced and $1.1 \%$ widowed. A total of $7.7 \%$ lived alone, $7.8 \%$ shared housing with people with no family ties; $17.8 \%$ lived with their partner and $66.7 \%$ lived with their family. The employment situation was as follows: $3.2 \%$ unemployed; $2.9 \%$ housewives; $35.2 \%$ students; $1.6 \%$ retired; and $57.1 \%$ active workers.

Table 1. Sociodemographic and lifestyle characteristics of the sample.

\begin{tabular}{cc}
\hline Variable & Percentage \\
\hline Gender & $15.7 \%$ \\
Man & $84.3 \%$ \\
\hline Woman & $33.61 \pm 13.03$ \\
\hline Cohabitation & $7.7 \%$ \\
Alone & $7.8 \%$ \\
I share a home with people with no family ties & $17.8 \%$ \\
Couple & $66.7 \%$ \\
\hline Family & $79.3 \%$ \\
\hline Nationality & $20.7 \%$ \\
\hline Spain & $32.6 \%$ \\
\hline Other & $67.4 \%$ \\
\hline Do you have a partner? & \\
\hline No & $51.9 \%$ \\
\hline Yes & $42 \%$ \\
\hline Marital status & $5 \%$ \\
\hline Single & $1.1 \%$ \\
\hline Work activity & $3.2 \%$ \\
\hline House master & \\
\hline
\end{tabular}


Table 1. Cont.

\begin{tabular}{|c|c|}
\hline Variable & Percentage \\
\hline Unemployed & $35.2 \%$ \\
\hline Student & $1.6 \%$ \\
\hline Retired & $0.8 \%$ \\
\hline Worker in the primary sector (agriculture, livestock, fishing and mining) & $2.5 \%$ \\
\hline \multicolumn{2}{|l|}{$\begin{array}{c}\text { Secondary sector worker (crafts, industry, construction and energy } \\
\text { production) }\end{array}$} \\
\hline $\begin{array}{l}\text { Tertiary sector worker (commerce, communications, finance, tourism, } \\
\text { hospitality, leisure and culture and administration and public services, } \\
\text { health and education). }\end{array}$ & $53.8 \%$ \\
\hline Physical activity $(p<0.05)$ & $43.8 \%$ \\
\hline No & $56.2 \%$ \\
\hline \multicolumn{2}{|l|}{ Yes } \\
\hline Sedentary $(p=0.68)$ & $21.1 \%$ \\
\hline No & $78.9 \%$ \\
\hline \multicolumn{2}{|l|}{ Yes } \\
\hline BMI & $5.9 \%$ \\
\hline Underweight & $55.3 \%$ \\
\hline Normal & $25.7 \%$ \\
\hline Overweight & $13.1 \%$ \\
\hline \multicolumn{2}{|l|}{ Obesity } \\
\hline Chronic Illness & $64.3 \%$ \\
\hline No & $35.7 \%$ \\
\hline \multicolumn{2}{|l|}{ Yes } \\
\hline Consumption of Stimulant Drinks & $23.1 \%$ \\
\hline No & $76.9 \%$ \\
\hline \multicolumn{2}{|l|}{ Yes } \\
\hline Tobacco & $83.1 \%$ \\
\hline No & $16.9 \%$ \\
\hline Yes & \\
\hline
\end{tabular}

In relation to physical activity, $56.2 \%$ of the participants said that they performed regular physical activity (30 min a day, 5 or more days a week). However, $78.9 \%$ acknowledged having sedentary periods during the day lasting two or more hours. Furthermore, $64.3 \%$ of the participants were healthy adults, while $35.7 \%$ had been diagnosed with a chronic disease, while $55.3 \%$ had a normal BMI, $25.7 \%$ were overweight and $13.1 \%$ obese. The consumption of stimulant beverages was frequent in the population, with $76.9 \%$ of the participants saying they consume coffee (mean $=1.89$ cups per day $\mathrm{SD}=1.03$ ), tea $($ mean $=1.33$ cups, $\mathrm{SD}=0.85)$ and $/$ or colas (mean $=1.40, \mathrm{SD}=0.75) .16 .9 \%$ of the participants smoke. Tobacco consumption was found to be similar among men and women (mean $=9$ cigarettes; $\mathrm{SD}=6.8)(p=0.83)$.

As for consumption (CRAFFT-A), $57 \%$ of the sample reported consuming at least one substance, compared to $43 \%$ who said they did not. There are differences between men and women, with men consuming more than women $(p<0.006)$. These differences are present in the consumption of alcohol $(p<0.002)$ and other psychostimulant substances $(p<0.015)$. 
Table 2. Descriptive for CRAFFT total score and Substance use (CRAFFT-A) and consequences of its consumption using CRAFFT-B score.

\begin{tabular}{|c|c|c|c|}
\hline Substance Use (CRAFFT-A) & General & Men & Women \\
\hline No & $43.0 \%$ & $32.8 \%$ & $44.9 \%$ \\
\hline Yes $(\geq 1$ substance $)$ & $57.0 \%$ & $67.2 \%$ & $55.1 \%$ \\
\hline \multicolumn{4}{|l|}{ CRAFFT_A1. Alcohol } \\
\hline No & $47.9 \%$ & $37.4 \%$ & $49.8 \%$ \\
\hline Yes & $52.1 \%$ & $62.6 \%$ & $50.2 \%$ \\
\hline \multicolumn{4}{|l|}{ CRAFFT_A2. Marijuana or hashish } \\
\hline No & $85.3 \%$ & $83.1 \%$ & $85.7 \%$ \\
\hline Yes & $14.7 \%$ & $16.9 \%$ & $14.3 \%$ \\
\hline \multicolumn{4}{|c|}{$\begin{array}{l}\text { CRAFFT_A3. Other psychostimulant } \\
\text { substances }\end{array}$} \\
\hline No & $91.5 \%$ & $86.8 \%$ & $92.4 \%$ \\
\hline Yes & $8.5 \%$ & $13.2 \%$ & $7.6 \%$ \\
\hline & Mean \pm SD & \multicolumn{2}{|c|}{$\begin{array}{l}\text { Confidence interval for the mean } \\
\qquad(95 \%)\end{array}$} \\
\hline CRAFFT total & $2.97 \pm 1.78$ & \multicolumn{2}{|c|}{$\begin{array}{l}\text { LL } 2.83 \\
\text { UL } 3.11\end{array}$} \\
\hline CRAFFT-B & $1.37 \pm 1.48$ & \multicolumn{2}{|c|}{$\begin{array}{l}\text { LL } 1.27 \\
\text { UL } 1.47\end{array}$} \\
\hline
\end{tabular}

SD: standard deviation; LL: lower limit; UL: upper limit.

\subsection{Relationship of Substance Use with Sociodemographic and Lifestyle Variables}

Substance use is associated with being male and with age. A total of $67.2 \%$ of men reported using harmful substances compared to $55.1 \%$ of women $(p=0.002)$. The older the participant, the less harmful substances consumed, while consumption is more frequent in participants of a younger average age (non-consumption 35.8 years, consumption 32.2 years) $(p=0.000)$. People who share housing with people without family ties $(23.4 \%)$ consume more than those who live with their family $(47.1 \%)(p<0.000)$. Marital status influences consumption; consumption is higher among single people $(60.4 \%)$ than married or cohabiting people $(p<0.042)$. The use of stimulant drinks $(p=0.002)$ and tobacco influences the consumption of psychostimulant substances $(p=0.000)$.

There is no relationship between consumption and physical activity $(p=0.552)$ or BMI $(p=0.953)$. However, consumption is higher among people who are sedentary, as $58.7 \%$ of sedentary people versus $50.6 \%$ of non-sedentary people consume ( $p=0.023)$. It is also higher in healthy people (who do not have a chronic disease), at $59.5 \%$ versus $52.8 \%$ $(p=0.024)$.

As can be seen in Table 2, 57\% of the participants report that they consume at least one harmful substance (alcohol, marijuana and/or another psychostimulant substance) The influence of the sociodemographic and lifestyle variables is different depending on the substance studied.

\subsubsection{Alcohol}

Alcohol consumption is higher in men than in women, with $62.6 \%$ of men reporting consumption compared to $50.2 \%$ of women $(p=0.002)$. It is also higher in people who share housing with people without family ties $(67 \%)$ than in people who live with their families $(49.6 \%)(p=0.009)$. It is related to people who drink stimulant beverages $(p=0.000)$ and who smoke $(p=0.000)$. There is no relationship between physical activity $(p=0.562)$ or a sedentary lifestyle $(p=0.068)$ in alcohol consumption. Consumption is lower among people with chronic disease $(47.8 \%)$ than in healthy people $(54.7 \%)(p=0.023)$. 


\subsubsection{Marijuana or Hashish}

There are no differences in marijuana or hashish use between men and women $(p=0.37)$. Its use is more prevalent in single people $(18.5 \%)$ than in married people $(10.2 \%)$ $(p=0.000)$. It is not related to the consumption of stimulant drinks $(p<0.05)$, but it is related to tobacco use $(p=0.000)$. Overall, $30.2 \%$ of smokers consumed marijuana compared to $11.6 \%$ of non-smokers. There was no relationship with physical activity or a sedentary lifestyle. However, higher levels of consumption were observed in people with normal weight $(18.4 \%)$ than in people with overweight $(9.7 \%)$ or obesity $(7.8 \%)(p=0.000)$. Consumption is lower in people with chronic disease, at $11.8 \%$ vs. $16.3 \%(p=0.034)$.

\subsubsection{Other Psychostimulant Substances}

A total of $13.2 \%$ of men say they consume other psychostimulant substances, versus $7.6 \%$ of women $(p=0.015)$. Single people are more frequent consumers $(p=0.000)$. This consumption is related to smoking ( $15.1 \%$ of smokers vs. $7.1 \%$ of non-smokers) $(p=0.000)$. This consumption is not related to physical activity $(p<0.05)$, but it is related to sedentary lifestyles, as consumption is higher among sedentary people $(9.4 \%$ vs. $5.1 \%)(p=0.031)$. The percentage of consumers is higher in people with a chronic disease than in healthy people ( $11.8 \%$ vs. $6.7 \%)$.

\subsection{Consequences of Substance Use}

The descriptive statistics for the CRAFFT total score are shown in Table 2. The overall mean score is 2.97, with a standard deviation of 1.78. No gender differences are observed $(p<0.05)$. The mean score of the CRAFFT-B is 1.37 with a standard deviation of 1.48 , with no significant differences according to sex.

As mentioned above, part B of the CRAFFT questionnaire refers to the personal and social consequences of substance use. The items with the highest percentage of responses are (in order) B5 (Have you ever FORGOTTEN what you did when taking alcohol, drugs or psychoactive substances?), to which $31.3 \%$ of the participants answered positively, B3 (Have you ever used alcoholic beverages, drugs or psychoactive substances to RELAX, to feel better about yourself or to integrate into a group?) with $29 \%$ of positive responses, B1 (Have you ever travelled in a CAR or vehicle driven by a person, including yourself, who has consumed alcohol, drugs or psychoactive substances?) answered positively by $24.5 \%$ of participants, and B6 (Have you ever consumed alcohol, drugs or psychoactive substances while ALONE and unaccompanied?) by $20 \%$. The only significant differences between men and women were observed in items B2 and B4, where the percentage of positive responses was higher in men than in women, of $17.6 \%$ vs. $11.3 \%(p=0.049)$ and $14.8 \%$ vs. $5.5 \%$, respectively $(p=0.000)$.

Significant differences were observed according to age (Table 3). The consequences of consumption occur more frequently in the younger population; the largest age differences were observed for item B5 (27.45 years vs. 35.71 years). The social and personal consequences (CRAFFT part B) according to the substance used are represented in Table 4.

Table 3. Age (years) differences in terms of consequences of substance use (CRAFFT-B).

\begin{tabular}{ccc}
\hline Items CRAFFT-B & Mean $( \pm$ SD) & $p$-Value \\
\hline B1 & $34.76( \pm 13.30)$ & \\
No & $30.21( \pm 11.50)$ & \\
Yes & $33.50( \pm 13.01)$ & \\
B2 & $29.27( \pm 12.08)$ & $p=0.000$ \\
No & \\
Yes & \\
\hline
\end{tabular}


Table 3. Cont.

\begin{tabular}{ccc}
\hline Items CRAFFT-B & Mean $( \pm \mathbf{S D})$ & $p$-Value \\
\hline B3 & $33.74( \pm 13.15)$ & \\
No & $31.73( \pm 12.44)$ & \\
Yes & $33.44( \pm 13.07)$ & \\
B4 & $29.13( \pm 11.35)$ & \\
No & & \\
Yes & $35.71( \pm 13.16)$ & \\
B5 & $27.45( \pm 10.68)$ & \\
No & & \\
Yes & $32.96( \pm 13.08)$ & \\
B6 & $33.84( \pm 12.52)$ & $p=0.012$ \\
No & & \\
Yes & &
\end{tabular}

Table 4. Social consequences according to the substance used.

\begin{tabular}{|c|c|c|c|c|}
\hline & Not Used & $\begin{array}{c}\text { Alcohol } \\
\text { (a) }\end{array}$ & $\begin{array}{c}\text { Marijuana } \\
\text { (With or Without Alcohol) } \\
\text { (b) }\end{array}$ & $\begin{array}{l}\text { Other Psychostimulant } \\
\text { Substances (With or Without } \\
\text { Alcohol, and/or Marijuana) } \\
\text { (c) }\end{array}$ \\
\hline $\begin{array}{c}\text { B1. Have you ever traveled in a CAR or vehicle } \\
\text { driven by a person (including you) who has } \\
\text { consumed alcohol, drugs or psychoactive } \\
\text { substances? } \\
\text { Yes }\end{array}$ & $\begin{array}{c}*(\mathrm{~b})(\mathrm{c}) \\
10 \%\end{array}$ & $26.9 \%$ & $53.1 \%$ & $52.4 \%$ \\
\hline $\begin{array}{c}\text { B2. Have your FRIENDS or your family ever } \\
\text { suggested that you reduce your consumption } \\
\text { of alcohol, drugs or psychoactive substances? } \\
\text { Yes }\end{array}$ & $\begin{array}{c}*(\mathrm{~b})(\mathrm{c}) \\
3.9 \%\end{array}$ & $11 \%$ & $23.6 \%$ & $21.4 \%$ \\
\hline $\begin{array}{l}\text { B3. Have you ever used alcoholic beverages, } \\
\text { drugs or psychoactive substances to RELAX, to } \\
\text { feel better about yourself or to join a group? } \\
\text { Yes }\end{array}$ & $\begin{array}{c}*(\mathrm{~b})(\mathrm{c}) \\
9.5 \%\end{array}$ & $30.3 \%$ & $44.1 \%$ & $50.5 \%$ \\
\hline $\begin{array}{c}\text { B4. Have you ever gotten into TROUBLE or } \\
\text { problems with alcohol, drugs or psychoactive } \\
\text { substances? } \\
\text { Yes }\end{array}$ & $\begin{array}{c}*(\mathrm{~b})(\mathrm{c}) \\
3.1 \%\end{array}$ & $6 \%$ & $11.0 \%$ & $15.0 \%$ \\
\hline $\begin{array}{l}\text { B5. Have you ever FORGOTTEN what you did } \\
\text { when you took alcohol, drugs or psychoactive } \\
\text { substances? } \\
\text { Yes }\end{array}$ & $\begin{array}{c}*(b) \\
13.7 \%\end{array}$ & $32.0 \%$ & $54.3 \%$ & $39.4 \%$ \\
\hline $\begin{array}{c}\text { B6. Have you ever consumed alcohol, drugs or } \\
\text { any psychoactive substance, finding yourself } \\
\text { ALONE and without company? } \\
\text { Yes }\end{array}$ & $\begin{array}{c}*(b)(c) \\
3.9 \%\end{array}$ & $19.0 \%$ & $31.5 \%$ & $47.0 \%$ \\
\hline
\end{tabular}

Data are expressed as percentages.; $\left(^{*}\right)$ Differences in non-consumption with categories (b) and (c).

\subsection{Mean CRAFFT B Score according to the Harmful Substance Used}

The CRAFFT questionnaire takes into account the consumption of alcohol, marijuana and/or other psychostimulant substances. An analysis of their behavior showed that there were no differences between people who only consumed marijuana and those who consumed alcohol in addition to marijuana $(p=0.599)$, but there were differences with people who only consumed alcohol $(p=0.013)$. Likewise, the behavior is similar if other psychostimulant substances are consumed compared to those who combine them with other substances (alcohol and/or marijuana) $(p>0.05)$.

Figure 1 shows the differences between the personal and social consequences of substance use. Significant differences are observed between non-consumption and consumption of any substance in the CRAFFT part B score. There are differences in scores 
between participants who drink alcohol and those who use marijuana with or without alcohol $(p<0.05)$ and between those who use alcohol and those who take other psychostimulant substances $(p<0.05)$. However, there is no difference in the CRAFFT-B score between those who use marijuana and those who use other psychostimulant substances $(p>0.05)$.

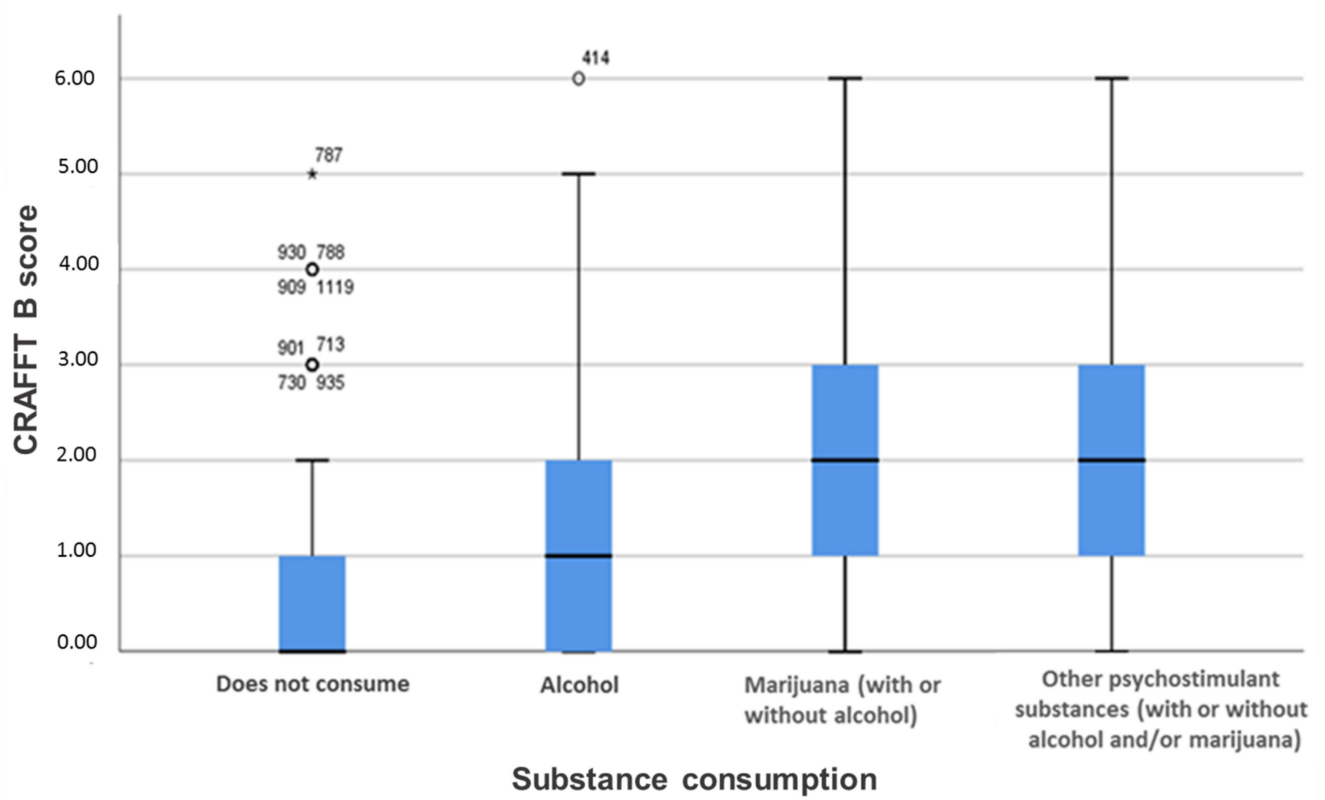

Figure 1. Substance use and consequences of its consumption.

The consequences of substance use are evaluated using the CRAFFT part B score. The data are expressed as the mean \pm standard deviation for each substance use.

Table 5 relates the consequences of consumption to the substance. The percentage of affirmative responses differs in items B1, B2, B3 between alcohol consumption and marijuana consumption (with or without alcohol) and alcohol and marijuana and/or other substances $(p<0.000)$. There are no differences between marijuana consumption (with or without alcohol) and the consumption of other psychostimulant substances (with or without alcohol and/or marijuana). In item B5, the percentage of affirmative responses was found to be higher in instances of marijuana use (with or without alcohol) $(p<0.000)$, while, in items B4 and B6 the percentage of affirmative responses is related to the use of other psychostimulant substances (with or without the presence of alcohol and/or marijuana) $(p<0.000)$.

Table 5. Mean score on the perceived health status scales, perceived stress scale and anxiety and depression scale according to consumption.

\begin{tabular}{cccc}
\hline Scale & $\begin{array}{c}\text { No Substance } \\
\text { Use }\end{array}$ & $\begin{array}{c}\text { Substance } \\
\text { Use }\end{array}$ & $p$-Value \\
\hline Perceived health statuss & $6.760( \pm 1.698)$ & $7.150( \pm 1.491)$ & 0.005 \\
\hline Perceived stress scale (EEP-10) & $20.563( \pm 5.123)$ & $20.349( \pm 5.279)$ & 0.222 \\
\hline Total score in Goldberg scale & $12.350( \pm 3.177)$ & $11.960( \pm 3.225)$ & 0.089 \\
\hline $\begin{array}{c}\text { Score in the Anxiety subscale } \\
\text { (Goldberg scale) }\end{array}$ & $7.332( \pm 1.655)$ & $7.177( \pm 1.708)$ & 0.232 \\
\hline $\begin{array}{c}\text { Score in the Depression subscale } \\
\text { (Goldberg scale) }\end{array}$ & $5.020( \pm 2.107)$ & $4.7779( \pm 2.153)$ & 0.112 \\
\hline
\end{tabular}

Data are expressed as the mean \pm standard deviation for each scale. 
3.5. Relationship between Substance Use, Perceived Health Status and Perceived Stress, Anxiety and Depression

The correlation between consumption (CRAFFT-A) and perceived health status is significant $(p<0.05)$, although the magnitude of the correlation is small $(0.07)$. The correlation of consumption with stress, anxiety and depression is not statistically significant.

The mean score of self-perceived health among substance users differs statistically from those who do not use them (Table 6).

Table 6. Mean score for anxiety, depression and perceived stress as a function of substance use.

\begin{tabular}{ccccc}
\hline Scale & No Use & Alcohol & $\begin{array}{c}\text { Marijuana } \\
\text { (With or Without } \\
\text { Alcohol) }\end{array}$ & $\begin{array}{c}\text { Other Psychostimulant } \\
\text { Substances (With or } \\
\text { Without Alcohol, and/or } \\
\text { Marijuana) }\end{array}$ \\
\hline $\begin{array}{c}\text { Score in the Anxiety subscale } \\
\text { (Goldberg scale) }\end{array}$ & $6.96( \pm 1.80)$ & $6.73( \pm 1.82)$ & $6.74( \pm 1.75)$ & $7.26( \pm 1.90)$ \\
\hline $\begin{array}{c}\text { Score in the Depression subscale } \\
\text { (Goldberg scale) }\end{array}$ & $4.81( \pm 2.13)$ & $4.51( \pm 2.15)$ & $4.53( \pm 2.06)$ & $4.87( \pm 2.20)$ \\
\hline Total score in Goldberg scale & $12.34( \pm 3.16)$ & $11.81( \pm 3.21)$ & $11.67( \pm 3.24)$ & $12.68( \pm 3.19)$ \\
\hline Perceived stress scale & $17.99( \pm 6.05)$ & $17.30( \pm 6.02)$ & $17.95( \pm 6.19)$ & $18.77( \pm 7.03)$ \\
\hline
\end{tabular}

Data are expressed as the mean \pm standard deviation for each scale.

There are differences between perceived health status and substance use (Figure 2) between the participants who report consuming alcohol and those who report not being consumers $(p=0.035)$. On a scale of 1 to 10 , people who consume alcohol rate their health at $7.52(\mathrm{SD}=1.34)$ compared to $7.19(\mathrm{SD}=1.65)$ for people who say they do not consume alcohol. No differences were observed in the other categories $(p>0.05)$.

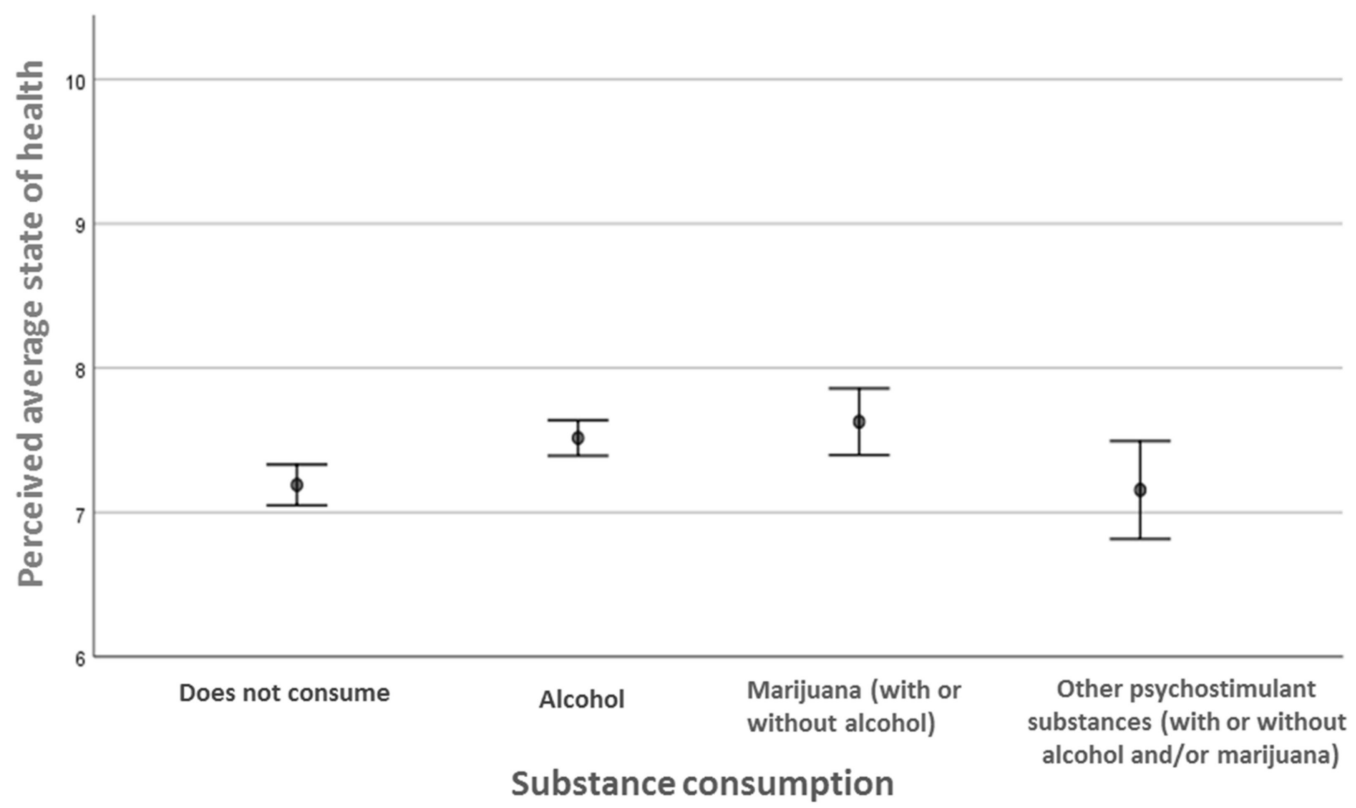

error bars: $95 \% \mathrm{Cl}$

Figure 2. Perceived health status as a function of substance use. Perceived state of health was evaluated on a scale of $0-10$. The data are expressed at mean \pm standard deviation for each substance use. 
No relationship was observed between perceived stress and substance use $(p>0.05)$. There is also no difference in the score obtained in the Goldberg anxiety-depression questionnaire (global score) and substance consumption $(p=0.051)$. No relationship between the score on the depression scale and the substance consumed was observed.

However, when the influence of substance consumption was analysed with the anxiety subscale, differences were observed between people who consumed alcohol and people who consumed other psychostimulant substances $(p=0.032)$. The score on the anxiety subscale is higher among people who consume psychostimulants (in combination with other substances or not) than those who consume alcohol.

\subsection{Variables Associated with Substance Use}

A binary logistic regression model was applied to determine the influence of variables related to substance use. Based on the variables that were found to be significant in the previous analyses, the sociodemographic and lifestyle factors were analyzed to explain and predict consumption in the study sample.

To this end, a backward statistical procedure was applied, taking the multiple logit regression model as the initial model that includes the main effects of all the explanatory variables, and including consumption as a response variable with two categories: no substance consumption (category 0) versus consumption (CRAFFT A > 0 category 1).

Analysis of the initial regression model indicates that the variables Chronic Illness, Anxiety (Goldberg), Depression (Goldberg) and Stress (EEP-10) do not produce significant results $(p=0.989, p=0.482, p=0.631$ and $p=0.867)$, and do not appear to be associated with substance use (CRAFFT-A).

The results of the variables included in the model are described below.

Sex has a statistically significant relationship with consumption. Being male increases the probability of consumption by 1.585 . Increasing age reduces the risk, with the risk reduced by $0.025 \%$ for each year. Cohabitation is also related to consumption, with people who live in families consuming the least; the risk is multiplied by 2.336 when sharing a house with people who are not family members.

Substance use is also related to the consumption of stimulant beverages and tobacco, which increase the risk by 1.677 and 2.579, respectively. A sedentary lifestyle is also a risk factor, increasing the probability of consumption by almost $50 \%$, although it did not reach statistical significance $(\mathrm{OR}=1.499)(p=0.058)$.

\subsection{Variables Associated with the Consequences of Substance Use}

The next step is to determine the variables associated with the consequences of substance use. Only people who consume at least one substance have been considered, since non-consumers did not answer part B of the CRAFFT questionnaire.

The variables included in the initial model are the same as those considered to determine whether or not the individual consumes substances (Table 7), with the addition of the variable of substance consumed ( 1 alcohol, 2 marijuana (with or without alcohol), 2 psychostimulant substances (with or without alcohol and/or marijuana) (Table 8).

The variables associated with each consequence vary (Table 9). Age influences behaviors B1, B4 and B5. In these cases, increasing age reduces the probability of the consequences. People who smoke in addition to consuming substances, receive up to three times more $(\mathrm{OR}=3.370)$ recommendations from family and friends to reduce their consumption. The type of substance use is a risk factor in behaviors B1, B3, B5, B6. Combining substances can increase the risk of driving a vehicle after having consumed them by up to 3.4 times. 
Table 7. Explanatory variables included in the initial model.

\begin{tabular}{|c|c|}
\hline Explanatory Variables & Categories \\
\hline Age (Years) & Numerical Variable \\
\hline Gender & $\begin{array}{c}1 \text { Man } \\
2 \text { Woman }\left(^{*}\right)\end{array}$ \\
\hline Cohabitation & $\begin{array}{c}1 \text { Alone } \\
2 \text { I share a home with people without family ties } \\
3 \text { Couple } \\
4 \text { Family }\left(^{*}\right)\end{array}$ \\
\hline Sedentary & $\begin{array}{l}\text { No }\left(^{*}\right) \\
\text { Yes }\end{array}$ \\
\hline Chronic illness & $\begin{array}{l}\text { No }\left(^{*}\right) \\
\text { Yes }\end{array}$ \\
\hline Tobacco & $\begin{array}{l}\text { No }\left(^{*}\right) \\
\text { Yes }\end{array}$ \\
\hline Stimulant drinks & $\begin{array}{l}\text { No }\left(^{*}\right) \\
\text { Yes }\end{array}$ \\
\hline Perceived health status & Numerical variable (Range $0-10$ ) \\
\hline Anxiety subscale (Goldberg) & Numerical variable (Range 0-9) \\
\hline Depression subscale (Goldberg) & Numerical variable (Range 0-9) \\
\hline Perceived stress scale & Numerical variable (Range $0-40$ ) \\
\hline
\end{tabular}

$\left({ }^{*}\right)$ Reference category in regression analysis.

Table 8. Final logistic regression model: Variables associated with consumption.

\begin{tabular}{ccccc}
\hline & $p$-Value & Exp(B) & \multicolumn{2}{c}{ 95\% C.I. Para EXP(B) } \\
\hline Age (years) & & & LL & UL \\
\hline Sex (1) & 0.001 & 0.975 & 0.961 & 0.989 \\
\hline Cohabitation: Family & 0.079 & 1.585 & 0.947 & 2.653 \\
\hline Cohabitation (1): Alone & 0.068 & & & \\
\hline $\begin{array}{c}\text { Cohabitation (2): I share a home with } \\
\text { people without family ties }\end{array}$ & 0.708 & 1.131 & 0.595 & 2.147 \\
\hline Cohabitation (3): Couple & 0.016 & 2.336 & 1.173 & 4.652 \\
\hline Consumption of stimulant drinks (1) & 0.163 & 1.360 & 0.883 & 2.094 \\
\hline Tobacco (1) & 0.009 & 1.677 & 1.138 & 2.472 \\
\hline Sedentary (1) & 0.000 & 2.579 & 1.642 & 4.05 \\
\hline Health condition & 0.058 & 1.499 & 0.986 & 2.279 \\
\hline
\end{tabular}

LL: lower limit; UL: upper limit. Model fit $\chi^{2}$ Hosmer-Lemeshow $=2315 p=0.970$.

Marijuana use (with or without alcohol) increases the risk of forgetfulness (CRAFFT item B5) by 2.33 times and the use of other psychostimulant substances (with or without alcohol and/or marijuana) almost triples the risk of solo use (OR = 2.965). 
Table 9. Final logistic regression model: Variables associated with consequences of consumption.

\begin{tabular}{|c|c|c|c|c|c|c|c|c|c|c|c|c|}
\hline & \multicolumn{2}{|c|}{ B1 } & \multicolumn{2}{|c|}{ B2 } & \multicolumn{2}{|c|}{ B3 } & \multicolumn{2}{|c|}{ B4 } & \multicolumn{2}{|c|}{ B5 } & \multicolumn{2}{|c|}{ B6 } \\
\hline & $p$ & $\operatorname{Exp}(B)$ & $p$ & $\operatorname{Exp}(B)$ & $p$ & $\operatorname{Exp}(B)$ & $p$ & $\operatorname{Exp}(B)$ & $p$ & $\operatorname{Exp}(B)$ & $p$ & $\operatorname{Exp}(B)$ \\
\hline Age (years) & 0.000 & 0.959 & - & - & - & - & 0.018 & 0.948 & 0.000 & 0.930 & - & - \\
\hline Gender (1) & - & - & - & - & - & - & 0.014 & 3.031 & & & - & - \\
\hline Cohabitation: Family & - & - & - & - & - & - & - & - & - & - & 0.029 & \\
\hline Cohabitation (1): Alone & - & - & - & - & - & - & - & - & - & - & 0.097 & 2.119 \\
\hline $\begin{array}{c}\text { Cohabitation (2): } \\
\text { I share a home with people } \\
\text { without family ties }\end{array}$ & - & - & - & - & - & - & - & - & - & - & 0.390 & 0.696 \\
\hline Cohabitation(3): Couple & - & - & - & - & - & - & - & - & - & - & 0.022 & 2.034 \\
\hline Chronic illness (1) & - & - & - & - & 0.081 & 0.655 & - & - & - & - & - & - \\
\hline $\begin{array}{l}\text { Consumption of stimulant } \\
\text { drinks (1) }\end{array}$ & - & - & - & - & - & - & - & - & - & - & - & - \\
\hline Tobacco (1) & 0.042 & 1.739 & 0.000 & 3.370 & - & - & - & - & - & - & 0.012 & 2.012 \\
\hline Sedentary (1) & - & - & - & - & - & - & - & - & - & - & & \\
\hline Health condition & - & - & - & - & - & - & 0.044 & 0.767 & - & - & - & - \\
\hline Perceived stress scale & 0.065 & 0.964 & - & - & - & - & 0.045 & 0.921 & - & - & - & - \\
\hline $\begin{array}{l}\text { Depression Subscale } \\
\text { (Goldberg) }\end{array}$ & - & - & 0.006 & 1.211 & 0.000 & 1.232 & 0.091 & 1.196 & 0.046 & 0.898 & 0.000 & 1.234 \\
\hline CRAFFT-A: Alcohol $\left(^{*}\right)$ & $0.000-$ & - & - & - & 0.001 & & - & - & 0.005 & & 0.001 & \\
\hline $\begin{array}{c}\text { CRAFFT-A: } \\
\text { Marijuana (with or without } \\
\text { alcohol) }\end{array}$ & 0.001 & 2.658 & - & - & 0.011 & 2.063 & - & - & 0.005 & 2.330 & 0.049 & 1.854 \\
\hline $\begin{array}{l}\text { CRAFFT-A: } \\
\text { Other psychostimulant } \\
\text { substances (with or without } \\
\text { alcohol and/or marijuana) }\end{array}$ & 0.000 & 3.405 & - & - & 0.001 & 2.784 & - & - & 0.024 & 2.022 & 0.000 & 2.965 \\
\hline
\end{tabular}

$\left.{ }^{*}\right)$ Reference category in regression analysis. Model fit B1 $\chi^{2}$ Hosmer-Lemeshow $=4.431 p=0.816$; Model fit $\mathrm{B} 2 \chi^{2}$ Hosmer-Lemeshow $=12.384 p=0.089$; Model fit B3 $\chi^{2}$ Hosmer-Lemeshow = 8.424 $p=0.393$; Model fit B4 $\chi^{2}$ Hosmer-Lemeshow $=5.044 p=0.753$; Model fit B5 $\chi^{2}$ Hosmer-Lemeshow $=4.162 p=0.842$; Model fit B5 $\chi^{2}$ Hosmer-Lemeshow $=6.715 p=0.568$.

\section{Discussion}

The main objective of Internet surveys investigating drug use behavior is to obtain valid and accurate measures of drug use in the population [66], and in our study, to obtain information on the personal and social consequences of drug use. Tools that use the Internet as an effective communication channel are an alternative for addressing the global problem of substance abuse, as this tends to be underreported [67]. A large number of studies conducted in recent decades have quite clearly underlined that self-administered questionnaires are more appropriate than other modes of data collection for collecting reports on sensitive behaviors such as this one [66,68]. Indeed, responses to self-administered questionnaires, whether completed with pen and paper or via a laptop computer, appear more reliable, and are particularly suitable for reporting behaviors that may compromise the respondent in some way, such as intimate or painful feelings, or illegal behaviors $[69,70]$. This could be attributed to the absence of a direct, identifiable witness, which therefore ensures the respondent's anonymity and greater freedom of expression on personal topics such as this [71].

A large percentage (almost $80 \%$ ) of Spanish families have an Internet connection, and $64.3 \%$ of the population uses the Internet on a daily basis [72] making it a crucial tool for population-based surveys as in the present study.

Our study showed that among the personal consequences of substance use, the item with the largest percentage of positive answers referred to forgetting personal experiences during use: "Do you ever FORGET things you did while using alcohol or drugs?". This 
result is supported by the well-known effects of substance abuse on the neurophysiology of brain circuits related to memory, such as those involving the hippocampus [73-76]. Study in humans have shown that marijuana use alters multiple brain functions, including memory, as shown by the deficit in working and short-term memory related to its use [77]. Cannabis users showed poorer learning and memory than tobacco users, suggesting an effect of long-term cannabis use on memory despite short-term abstinence [78,79]. With respect to the effects of alcohol exposure on cognition, at higher doses it affects the performance of cognitive tasks that depend on the hippocampus, whereas at low doses it has no effect or even facilitates working memory when performing certain tasks [76]. Among the personal consequences, the item "Do you ever use alcohol or drugs to RELAX, feel better about yourself, or fit in? " is the second most rated in our study. This use could be influenced by social culture, since some substances such as marijuana have been used worldwide for medical, recreational and spiritual purposes for thousands of years [80], and in the particular case of cannabis, because of the anxiolytic effects derived from its consumption [81]. A higher proportion of users of marijuana and/or other psychostimulant substances (with or without alcohol) reported "using to relax". Although people tend to have multiple reasons for using substances, these results would be in line with those found in various studies on the motivational aspects of marijuana use, in which among the main reasons for use are to relax, wanting to feel better and to forget problems [82]. This is alarming given that Patrick et al. [82] found that motives related to Get High + Relax Reasons are considered potential reasons to continue consumption after the substance has been tried. Meanwhile, alcohol is a legally permitted substance that is widely consumed throughout the world, in both social and cultural settings [83]. This widespread use and its extensive use in social settings would justify the responses in this study that relate substance use to social integration. In a study published by Skobic et al. [84], the authors conducted a telephone interview with a sample size similar to this study of 1639 participants, and they found a high prevalence of marijuana use for sleep induction/relaxation. Substance use and its use to relax or "feel better" may also be related to the presence of associated comorbidity, such as major depressive disorder (MDD). This disorder can profoundly alter the patient's social, family and work performance, and is the most prevalent comorbid mental disorder among people with substance use disorders [85]. Studies such as that of López and Becoña [86] evidence a correlation between cocaine use and depressive symptomatology. The results of our study found a trend towards a significant association between the score obtained in the Goldberg anxiety-depression questionnaire and substance consumption $(p=0.051)$. The results of our study for the consumption of psychostimulants for relaxation purposes may have been influenced by the existence of comorbidity related to anxiety, since the score on the anxiety subscale was higher in people who consume this type of substance. One third of the participants in our study say that they have at some point forgotten what they did when they drank alcohol, or took drugs or other psychoactive substances. This is the most frequently reported personal and social consequence of drug consumption, although it is strongly modulated by age [61].

Alcohol intoxication produces effects that can impair judgment and decision making, and increase participation in risky behaviors including drunk driving [87-89]. The study by Motschman et al. [87] reported that individuals who are under the influence of alcohol may perceive themselves as "unsafe" to drive, but "safe enough" to drive short distances, especially when their blood alcohol concentration is decreasing. Driving under the influence of alcohol or other substances is one of the most frequent consequences of alcohol use in our sample, with approximately $30 \%$ of the participants reporting having driven under the influence of at least one substance. In our study, this behavior is not related to gender, while other studies indicate that these risk behaviors are more frequent among males than females [90,91]. The frequency of this behavior decreases with age, although these risky driving behaviors are related to the perception of low risk and impulsiveness of youth [92]. The type of consumption influences the consequences of consumption; alcohol with another substance (marijuana or another psychostimulant) can therefore triple the 
risk. Sewell et al. [93] note that the combination of alcohol and cannabis results in greater impairment even at doses that would be negligible if they were of either drug alone.

Regarding the differences in personal and social consequences according to age, the results of our study show that forgetfulness is more frequent among young people. This could be due to a pattern of consumption with an increasing trend in this population group, as reflected in the 2021 Report issued by the Spanish Observatory on Drugs and Addictions [94]. According to this report, the prevalence of consumption (last year) is higher in the 15-34 age group, and in the case of alcohol, binge drinking has generally experienced an upward trend since 2007. Heavy drinking and binge drinking are more prevalent among males and are more heavily concentrated in the 15-34 age group. The alcoholic amnesia that causes forgetfulness occurs when high blood alcohol levels are reached in short periods of time, and are more related to the speed of intake than to the quantity [95].

As for the differences in personal and social consequences according to age, older people drink alone more often than younger people. In Spain, alcohol consumption in young people is most commonly associated with the "botellón" phenomenon. Among young people, there has been a shift away from a "Mediterranean" model of alcohol consumption, associated with meals, to an "Anglo-Saxon" model characterized by consuming drinks with higher alcohol content, in larger quantities and over shorter periods of time [96]. As for illicit psychostimulants, these are used more in specific subgroups or cultures according to Favrod-Coune and Broers [97]. Cannabis is the most widely used illicit drug among adolescents and young adults [98], and its effects have traditionally been considered less harmful than those associated with the abuse of alcohol and other illicit substances (e.g., cocaine and amphetamines) and injecting drugs [99]. According to data published by the Spanish Observatory on Drugs and Addictions [94], young people generally have a low perception of the risks associated with cannabis use, and in addition, after alcohol and tobacco, it is the psychoactive substance perceived as the most available by this population. These factors could influence the minimization of the adverse effects derived from the use of some substances among young people and their widespread use in social settings. Furthermore, in our study, living together as a family constitutes a protective factor for consumption, so that young people could limit their use of toxic substances to leisure time in the company of other young people. Confirming the results about the effect of age on abuse pattern, increasing age represents a protective factor. This may be due to the social roles associated with increased opportunities for exploration and experimentation among the younger population [100], as opposed to the social commitments of adulthood, such as being married, having children, and working full-time [101]. Although the family environment can act as a risk factor in the consumption of harmful substances, in our study, people who live in families, as opposed to those who share housing with people with whom they have no family ties (or friends), presented a lower risk of consumption. This could be in line with Brook et al. [102], who state that there are protective factors in the family environment such as conventionality, balance, maternal adjustment and strong attachment bonds in the family, which can mitigate the vulnerability of children to drug use when they relate to friends and peers who consume drugs.

We observed that being male increases the probability of consumption for almost all substances (except for marijuana/hashish, which was similar for both males and females). This finding, together with those systematically reported in previous studies $[103,104]$, shows how the use of harmful substances continues to be an issue related to masculinity. This could be linked to the social mandates that men receive from birth, such as risk-taking or avoiding showing their emotions as ways of publicly affirming their masculinity [105]. Another possible explanation for this finding is the greater social rejection of illicit drug use among women [8]. In addition, the higher prevalence of impulsivity traits observed among males [106] and the fact that impulsivity is associated with a predisposition to the use and abuse of toxic substances and the pursuit of risky behaviors [107] could also partially explain a higher consumption of harmful substances among the male population. 
However, it is important to note that in recent years, a trend towards a homogenization of consumption patterns among both sexes, particularly among the younger population, has been observed in most studies [8,108]. In addition, we found that certain health habits such as smoking tobacco and the intake of stimulant beverages increase the likelihood of substance use. Previous research has generally shown that tobacco use alone predicts both alcohol abuse and illicit drug use $[109,110]$. These results could be explained by the gateway hypothesis, which holds that the use of a legal and easily accessible harmful substance, such as tobacco, increases the risk of starting to use another, probably more harmful, drug [111]. Meanwhile, a systematic review conducted by McKetin et al. [112] revealed that combining alcohol with caffeinated energy drinks increased the desire to continue consuming more alcohol. Approximately $12.4 \%$ of the participants indicated that their family, friends or people around them had recommended that they reduce their consumption at some point. The family may therefore be a potential resource for treatment and rehabilitation [113]. Tobacco use increases this outcome $(\mathrm{OR}=3.370)$. Tobacco has been used as a predictor of other substance abuse, and as such some authors support simultaneous treatment to quit tobacco and other substances [114]. Some studies report that substance use is higher in people with chronic diseases. Wu et al. [115] found that the number of chronic diseases correlated significantly and positively with the severity of drug use. However, in our case, people with chronic illnesses report not using consumption to relax $(\mathrm{OR}=0.655)$. The literature shows patterns of association between substance use, mainly of alcohol, and depressive symptoms [116,117]. A study conducted with adolescents revealed that approximately $5 \%$ of the sample openly admitted to using drugs due to sadness, feelings of failure, lack of energy and because they have family problems.

According to our data, stress reduces the probability of getting into trouble for substance use. Low et al. [118] found that stress or health concerns are inversely related to heavy drinking, perhaps due to a reflection that many young adolescents are aware of, and perhaps fearful of, the detrimental health effects of drinking.

Twenty percent of the sample reported consuming alone. In our research this situation increases among people living alone, users who are also smokers and with symptoms of depression. Some authors indicate the importance of ascertaining the context where it takes place in order to understand the risks [119]. A person who consumes alone tends to manifest negative affective traits and depressive symptoms to a greater extent [120]. The predictive model identified in our study has attempted to relate the social and personal consequences of substance use/abuse to some well-known sociodemographic and lifestyle variables, such as age, sex, smoking, stress level and depressive symptoms [94,100,103,104,109,110,114,116-118,120], while others are new, e.g., living alone or with family or a friend, the presence of chronic disease, sedentary lifestyle and perceived health status. These warrant further research in order to establish health-promotion strategies and policies for individuals who are more vulnerable or present risk factors to the adverse personal and social consequences of drug abuse. The COVID-19 pandemic began during the study, after which many people changed their lifestyles, and many started to work from home or lost their jobs. These factors may have contributed to the increase in using certain substances. The COVID-19 pandemic has led to measures of social distancing and confinement around the world to reduce the spread of the SARS-CoV-2 virus. These measures could lead to an unpleasant experience after separation from friends and family, and the limitation or prohibition of many daily activities (work, leisure, schools, sport). This situation may induce stress and lead to mental health problems, including an increase in the use of toxic substances [121-123]. According to a study conducted through a survey of 3632 participants from Belgium, during confinement, respondents consumed slightly more alcohol and smoked slightly more cigarettes compared to the previous period without confinement [122]. With respect to cannabis, no significant changes in consumption were observed in study performed in Belgium. In Spain, however, data from the Spanish Observatory on Drugs and Addictions (OEDA)-COVID 2020 survey [124], part of the National Plan on Drugs (DGPNSD) of the Ministry of Health and conducted by telephone interviewing 8780 people, show that the measures imposed to control the pandemic have especially reduced 
the consumption of cannabis (down 17\%) and alcoholic beverages (down 8\%), especially in young people, in whom the drop in alcohol consumption was as much as $25 \%$. High alcohol consumption in the form of alcohol intoxication also decreased during the pandemic (prevalence of alcohol intoxication before the pandemic was estimated around $17.2 \%$ and during the pandemic $9.7 \%$; the decrease in the $15-19$ years' age group was $25 \%$ ). According to this survey, tobacco consumption decreased in Spain during the pandemic (prevalence of consumption before the pandemic $29.1 \%$ and during the pandemic $27.7 \%$ ), except among women aged 25-34 years and 45-54 years, groups in which prevalence remains more or less stable. With respect to the use of hypnosedatives without prescription, an increase in use was observed during the Covid-19 pandemic (prevalence of use before the pandemic 1.9\% and during the pandemic 3.1\%). This increase was observed in all age groups and in both sexes, being higher in women. The OEDA-COVID (2020) survey also reveals that cocaine use, which is relatively rare, decreased during the pandemic, from $1.4 \%$ before the pandemic to $1 \%$ during the pandemic. On the other hand, with respect to persons over 64 years of age who were surveyed, the data show a decrease in the consumption of alcoholic beverages, from a prevalence of $34.2 \%$ to $31.8 \%$. With respect to tobacco consumption, there was also a decrease in consumption during the pandemic, from a prevalence of $10.9 \%$ to $8.9 \%$. The use of other psychoactive substances such as non-prescription hypno-sedatives, non-prescription opioid analgesics, cannabis and cocaine was not detected in this population group.

Author Contributions: Conceptualization, M.L.B.-T., V.I.-d.-V., R.N.-M. and O.C.; methodology, M.L.B.-T., V.I.-d.-V., R.N.-M. and O.C.; formal analysis, M.L.B.-T., and O.C.; investigation, M.L.B.-T., V.I.-d.-V., R.N.-M. and O.C.; data collection, M.L.B.-T., V.I.-d.-V., R.N.-M. and O.C.; writing-original draft preparation, M.L.B.-T., V.I.-d.-V., R.N.-M. and O.C.; writing-review and editing, M.L.B.-T., R.N.-M. and O.C. All authors have read and agreed to the published version of the manuscript.

Funding: This research was funded by project Grups Emergents number GV/2021/137 from Conselleria de Sanitat-Generalitat Valenciana (Spain) (Principal Investigator Rut Navarro-Martínez).

Institutional Review Board Statement: The study was conducted according to the guidelines of the Declaration of Helsinki, and approved by the Human Research Ethics Committee of the University of Valencia (Valencia, Spain) (procedure number 1,232,539, dated 21 May 2020).

Informed Consent Statement: Not applicable.

Data Availability Statement: The data presented in this study are available on request with scientific purpose from the corresponding author.

Conflicts of Interest: The authors declare no conflict of interest.

\section{References}

1. Navarro-Martínez, R.; Chover-Sierra, E.; Colomer-Pérez, N.; Vlachou, E.; Andriuseviciene, V.; Cauli, O. Sleep quality and its association with substance abuse among university students. Clin. Neurol. Neurosurg. 2020, 1, 188. [CrossRef] [PubMed]

2. Wicki, M.; Kuntsche, E.; Gmel, G. Drinking at European universities? A review of students' alcohol use. Addict. Behav. 2010, 35, 913-924. [CrossRef] [PubMed]

3. Primack, B.A.; Kim, K.H.; Shensa, A.; Sidani, J.E.; Barnett, T.E.; Switzer, G.E. Tobacco, marijuana, and alcohol use in university students: A cluster analysis. J. Am. Coll. Health 2012, 60, 374-386. [CrossRef] [PubMed]

4. García Montes, J.M.; Zaldívar Basurto, F.; Moreno Montoya, M.; Flores Cubos, P. Relationship between drug use and psychopathological variables of risk in university students. Psicothema 2013, 25, 433-439. [PubMed]

5. Davoren, M.P.; Shiely, F.; Byrne, M.; Perry, I.J. Hazardous alcohol consumption among university students in Ireland: A cross-sectional study. BMJ Open 2015, 5, e006045. [CrossRef]

6. Carey, K.B.; Scott-Sheldon, L.A.J.; Carey, M.P.; DeMartini, K.S. Individual-level interventions to reduce college student drinking: A meta-analytic review. Addict. Behav. 2007, 32, 2469-2494. [CrossRef]

7. Aresi, G.; Moore, S.; Marta, E. Italian credit mobility students significantly increase their alcohol intake, risky drinking and related consequences during the study abroad experience. Alcohol Alcohol. 2016, 51, 723-726. [CrossRef]

8. Tejedor-Cabrera, C.; Cauli, O. Alcohol and Cannabis Intake in Nursing Students. Medicina 2019, 55, 628. [CrossRef] [PubMed]

9. Colomer-Pérez, N.; Chover-Sierra, E.; Navarro-Martínez, R.; Andriusevičienè, V.; Vlacho, E.; Cauli, O. Alcohol and drug use in european university health science students: Relationship with self-care ability. Int. J. Environ. Res. Public Health 2019, $16,5042$. [CrossRef] 
10. Siliquini, R.; Piat, S.C.; Alonso, F.; Druart, A.; Kedzia, M.; Mollica, A.; Siliquini, V.; Vanko, D.; Villerusa, A.; Manzoli, L.; et al. A European study on alcohol and drug use among young drivers: The TEND by Night study design and methodology. BMC Public Health 2010, 10, 205. [CrossRef] [PubMed]

11. Chhatre, S.; Cook, R.; Mallik, E.; Jayadevappa, R. Trends in substance use admissions among older adults. BMC Health Serv. Res. 2017, 17, 584. [CrossRef]

12. Satre, D.D.; Merten, J.R.; Areán, P.A.; Weisner, C. Five-year alcohol and drug treatment outcomes of older adults versus middle-aged and younger adults in a managed care program. Addiction 2004, 99, 1286-1297. [CrossRef]

13. Delker, E.; Brown, Q.; Hasin, D.S. Alcohol Consumption in Demographic Subpopulations: An Epidemiologic Overview. Alcohol Res. 2016, 38, 7-15.

14. Wang, Y.P.; Andrade, L.H. Epidemiology of alcohol and drug use in the elderly. Curr. Opin. Psychiatry 2013, 26, 343-348. [CrossRef] [PubMed]

15. Glei, D.A.; Weinstein, M. Drug and Alcohol Abuse: The Role of Economic Insecurity. Am. J. Health Behav. 2019, 43, 838-857. [CrossRef] [PubMed]

16. Worobec, T.G.; Turner, W.M.; O'Farrell, T.J.; Cutter, H.S.; Bayog, R.D.; Tsuang, M.T. Alcohol use by alcoholics with and without a history of parental alcoholism. Alcohol. Clin. Exp. Res. 1990, 14, 887-892. [CrossRef] [PubMed]

17. White, A.M.; Castle, I.P.; Hingson, R.W.; Powell, P.A. Using Death Certificates to Explore Changes in Alcohol-Related Mortality in the United States, 1999 to 2017. Alcohol. Clin. Exp. Res. 2020, 44, 178-187. [CrossRef] [PubMed]

18. Han, B.H.; Sherman, S.E.; Palamar, J.J. Prescription opioid misuse among middle-aged and older adults in the United States, 2015-2016. Prev. Med. 2019, 121, 94-98. [CrossRef] [PubMed]

19. Trostler, M.; Li, Y.; Plankey, M.W. Prevalence of binge drinking and associated co-factors among medical students in a U.S. Jesuit University. Am. J. Drug Alcohol Abus. 2014, 40, 336-341. [CrossRef]

20. Hepworth, J.; Schofield, T.; Leontini, R.; Germov, J. Alcohol-related harm minimization practices among university students: Does the type of residence have an impact? Br. J. Health Psychol. 2018, 23, 843-856. [CrossRef]

21. Zweben, J.E.; Clark, H.W.; Smith, D.E. Traumatic experiences and substance abuse: Mapping the territory. J. Psychoact. Drugs 1994, 26, 327-344. [CrossRef]

22. Logrip, M.L.; Zorrilla, E.P.; Koob, G.F. Stress modulation of drug self-administration: Implications for addiction comorbidity with post-traumatic stress disorder. Neuropharmacology 2012, 62, 552-564. [CrossRef]

23. McPherson, K.E.; Kerr, S.; Morgan, A.; McGee, E.; Cheater, F.M.; McLean, J.; Egan, J. The association between family and community social capital and health risk behaviours in young people: An integrative review. BMC Public Health 2013, 13, 971. [CrossRef]

24. Glynn, T.J. Families and drugs: A life-span research approach. Am. J. Drug Alcohol Abus. 1982, 9, 397-412. [CrossRef]

25. Stone, A.M.; Merlo, L.J. Psychiatric medication-seeking beliefs and behaviors among college students. Am. J. Drug Alcohol Abus. 2012, 38, 314-321. [CrossRef] [PubMed]

26. Tosevski, D.L.; Milovancevic, M.P.; Gajic, S.D. Personality and psychopathology of university students. Curr. Opin. Psychiatry 2010, 23, 48-52. [CrossRef]

27. Tembo, C.; Burns, S.; Kalembo, F. The association between levels of alcohol consumption and mental health problems and academic performance among young university students. PLoS ONE 2017, 12, e0178142. [CrossRef]

28. Charlet, K.; Heinz, A. Harm reduction-a systematic review on effects of alcohol reduction on physical and mental symptoms. Addict. Biol. 2017, 22, 1119-1159. [CrossRef] [PubMed]

29. Pacher, P.; Steffens, S.; Haskó, G.; Schindler, T.H.; Kunos, G. Cardiovascular effects of marijuana and synthetic cannabinoids: The good, the bad, and the ugly. Nat. Rev. Cardiol. 2018, 15, 151-166. [CrossRef] [PubMed]

30. Day, E.; Rudd, J.H.F. Alcohol use disorders and the heart. Addiction 2019, 114, 1670-1678. [CrossRef]

31. Mostofsky, E.; Chahal, H.S.; Mukamal, K.J.; Rimm, E.B.; Mittleman, M.A. Alcohol and Immediate Risk of Cardiovascular Events: A Systematic Review and Dose-Response Meta-Analysis. Circulation 2016, 133, 979-987. [CrossRef]

32. Davis, L.; Uezato, A.; Newell, J.M.; Frazier, E. Major depression and comorbid substance use disorders. Curr. Opin. Psychiatry 2008, 21, 14-18. [CrossRef] [PubMed]

33. Fiorentini, A.; Volonteri, L.S.; Dragogna, F.; Rovera, C.; Maffini, M.; Mauri, M.C.; Altamura, C.A. Substance-induced psychoses: A critical review of the literature. Curr. Drug Abus. Rev. 2011, 4, 228-240. [CrossRef]

34. Penning, R.; Veldstra, J.L.; Daamen, A.P.; Olivier, B.; Verster, J.C. Drugs of abuse, driving and traffic safety. Curr. Drug Abus. Rev. 2010, 3, 23-32. [CrossRef]

35. Bishop, C.A.; Liu, S.; Stephens, A.N.; Fitzharris, M. Associations between alcohol consumption patterns and attitudes towards alcohol interlocks. Accid. Anal. Prev. 2017, 108, 83-90. [CrossRef] [PubMed]

36. Bondallaz, P.; Favrat, B.; Chtiou, H.; Fornari, E.; Maeder, P.; Giroud, C. Cannabis and its effects on driving skills. Forensic Sci. Int. 2016, 268, 92-102. [CrossRef]

37. Hines, D.A.; Douglas, E.M. Alcohol and drug abuse in men who sustain intimate partner violence. Aggress. Behav. 2012, 38, 31-46. [CrossRef]

38. Lennox, R.D.; Scott-Lennox, J.A.; Holder, H.D. Substance abuse and family illness: Evidence from health care utilization and cost-offset research. J. Ment. Health Adm. 1992, 19, 83-95. [CrossRef] 
39. Macy, R.J.; Goodbourn, M. Promoting successful collaborations between domestic violence and substance abuse treatment service sectors: A review of the literature. Trauma Violence Abus. 2012, 13, 234-251. [CrossRef]

40. Hawkins, J.D.; Catalano, R.F.; Miller, J.Y. Risk and protective factors for alcohol and other drug problems in adolescence and early adulthood: Implications for substance abuse prevention. Psychol. Bull. 1992, 112, 64-105. [CrossRef] [PubMed]

41. Henkel, D. Unemployment and substance use: A review of the literature (1990-2010). Curr. Drug Abus. Rev. 2011, 4, 4-27. [CrossRef] [PubMed]

42. Kerr, D.C.R.; Capaldi, D.M. Introduction to the special section on the intergenerational transmission of risk for substance use Psychol. Addict. Behav. 2020, 34, 811-817. [CrossRef] [PubMed]

43. Piazza, P.V.; Le Moal, M.L. Pathophysiological basis of vulnerability to drug abuse: Role of an interaction between stress, glucocorticoids, and dopaminergic neurons. Annu. Rev. Pharmacol. Toxicol. 1996, 36, 359-378. [CrossRef]

44. Knight, J.R.; Sherritt, L.; Shrier, L.A.; Harris, S.K.; Chang, G. Validity of the CRAFFT substance abuse screening test among adolescent clinic patients. Arch. Pediatr. Adolesc. Med. 2002, 156, 607-614. [CrossRef] [PubMed]

45. Sinha, R. Chronic stress, drug use, and vulnerability to addiction. Ann. N. Y. Acad. Sci. 2008, 1141, 105-130. [CrossRef] [PubMed]

46. Schwabe, L.; Dickinson, A.; Wolf, O.T. Stress, habits, and drug addiction: A psychoneuroendocrinological perspective. Exp. Clin. Psychopharmacol. 2011, 19, 53-63. [CrossRef]

47. Boot, C.; Rosiers, J.F.; Meijman, F.J.; Van Hal, G.F. Consumption of tobacco, alcohol and recreational drugs in university students in Belgium and the Netherlands: The role of living situation. Int. J. Adolesc. Med. Health 2010, 22, 527-534. [CrossRef] [PubMed]

48. Horigian, V.E.; Schmidt, R.D.; Feaster, D.J. Loneliness, Mental Health, and Substance Use among US Young Adults during COVID-19. J. Psychoact. Drugs 2021, 53, 1-9. [CrossRef]

49. Victorio-Estrada, A.; Mucha, R.F. The Inventory of Drinking Situations (IDS) in current drinkers with different degrees of alcohol problems. Addict. Behav. 1997, 22, 557-565. [CrossRef]

50. Miller, P.G.; Sønderlund, A.L. Using the internet to research hidden populations of illicit drug users: A review. Addiction 2010, 105, 1557-1567. [CrossRef]

51. Eysenbach, G.; Wyat, J. Using the Internet for surveys and health research. J. Med. Internet Res. 2002, 4, 76-94. [CrossRef] [PubMed]

52. Kazemi, D.M.; Borsari, B.; Levine, M.J.; Dooley, B. Systematic review of surveillance by social media platforms for illicit drug use. J. Public Health 2017, 39, 763-776. [CrossRef] [PubMed]

53. European Web Survey on Drugs: Patterns of Use. Available online: https://www.emcdda.europa.eu/activities/european-websurvey-on-drugs_en\#section4 (accessed on 20 October 2021).

54. McCabe, R.E.; Chudzik, S.M.; Antony, M.M.; Young, L.; Swinson, R.P.; Zolvensky, M.J. Smoking behaviors across anxiety disorders. J. Anxiety Disord. 2004, 18,7-18. [CrossRef]

55. Gassman, R.A.; Dutta, T.; Agley, J.; Jayawardene, W.; Jun, M. Social Media Outrage in Response to a School-Based Substance Use Survey: Qualitative Analysis. J. Med. Internet Res. 2019, 21, e15298. [CrossRef] [PubMed]

56. Vandrey, R.; Stitzer, M.L.; Mintzer, M.Z.; Huestis, M.A.; Murray, J.A.; Lee, D. The dose effects of short-term dronabinol (oral THC) maintenance in daily cannabis users. Drug Alcohol Depend. 2013, 128, 64-70. [CrossRef]

57. Matias, J.; Kalamara, E.; Mathis, F.; Skarupov, K.; Noor, A.; Singleton, N. The use of multi-national web surveys for comparative analysis: Lessons from the European Web Survey on Drugs. Int. J. Drug. Policy 2019, 73, 235-244. [CrossRef]

58. Aguilar-Barojas, S. Formulas for the calculation of the sample in health research. Salud Tabasco 2005, 11, 333-338.

59. García-García, J.A.; Reding-Bernal, A.; López-Alvarenga, J.C. Calculation of the sample size in research in medical education. Res. Med. Educ. 2013, 2, 217-224.

60. National Institute of Statistics. Population Figures; National Institute of Statistics: Madrid, Spain, 2021.

61. Rial, A.; Kim-Harris, S.; Knight, J.R.; Araujo, M.; Gómez, P.; Braña, T.; Varela, J.; Golpe, S. Empirical validation of the CRAFFT Abuse Screening Test in a Spanish sample. Adicciones 2019, 31, 160-169. [CrossRef] [PubMed]

62. Cohen, S.; Kamarck, T.; Mermelstein, R. A Global Measure of Perceived Stress. J. Health Soc. Behav. 1983, 24, 385. [CrossRef] [PubMed]

63. Remor, E. Psychometric properties of a European Spanish version of the Perceived Stress Scale (PSS). Span. J. Psychol. 2006, 9, 86-93. [CrossRef]

64. Goldberg, D.P.; Hillier, V.F. A scaled version of the General Health Questionnaire. Psychol. Med. 1979, 9, 139-145. [CrossRef]

65. Montón, C.; Pérez Echeverría, M.J.; Campos, R.; García Campayo, J.; Lobo, A. Anxiety scales and Goldberg's depression: An efficient interview guide for the detection of psychologic distress. Aten. Primaria 1993, 12, 345-349. [PubMed]

66. Adlaf, E.M. Collecting Drug Use Data from Different Populations. In Epidemiology of Drug Abuse; Sloboda, Z., Ed.; Springer: Boston, MA, USA, 2005; pp. 99-112.

67. Harrison, L.; Hughes, A. Introduction-The validity of self-reported drug use: Improving the accuracy of survey estimates. NIDA Res. Monogr. 1997, 167, 1-16.

68. Tourangeau, R.; Smith, T.W. Asking Sensitive Questions: The Impact of Data Collection Mode, Question Format, and Question Context. Public Opin. Q. 1966, 60, 275-304. [CrossRef]

69. Babor, T.F.; Krenzler, H.R.; Lauerman, R.J. Early detection of harmful alcohol consumption: Comparison of clinical, laboratory, and self-reportscreening procedures. Addict. Behav. 1989, 14, 139-157. [CrossRef] 
70. Tourangeau, R.; Rips, L.J.; Rasinski, K. The Psychology of Survey Response; Cambridge University Press: Cambridge, UK, 2000; pp. 1-22.

71. Rouse, B.A.; Kozel, N.J.; Richards, L.G. Self-Report Methods of Estimating Drug Use: Meeting Current Challenges to Validity; Department of Health and Human Services: Rockville, MD, USA, 1985; pp. 22-30.

72. Rodríguez-Martos, A.; Castellano, Y. Web-based screening and advice for hazardous drinkers: Use of a Spanish site. Drug Alcohol. Rev. 2009, 28, 54-59. [CrossRef]

73. Battisti, R.A.; Roodenrys, S.; Johnstone, S.J.; Respondek, C.; Hermens, D.F.; Solowij, N. Chronic use of cannabis and poor neural efficiency in verbal memory ability. Psychopharmacology 2010, 209, 319-330. [CrossRef]

74. Hoffman, A.F.; Oz, M.; Yang, R.; Lichtman, A.H.; Lupica, C.R. Opposing actions of chronic Delta9-tetrahydrocannabinol and cannabinoid antagonists on hippocampal long-term potentiation. Learn. Mem. 2007, 14, 63-74. [CrossRef] [PubMed]

75. Kawamura, Y.; Fukaya, M.; Maejima, T.; Yoshida, T.; Miura, E.; Watanabe, M.; Ohno-Shosaku, T.; Kano, M. The CB1 cannabinoid receptor is the major cannabinoid receptor at excitatory presynaptic sites in the hippocampus and cerebellum. J. Neurosci. Off. J. Soc. Neurosci. 2006, 26, 2991-3001. [CrossRef]

76. Van Skike, C.E.; Goodlett, C.; Matthews, D.B. Acute alcohol and cognition: Remembering what it causes us to forget. Alcohol 2019, 79, 105-125. [CrossRef]

77. Riedel, G.; Davies, S.N. Cannabinoid function in learning, memory and plasticity. Handb. Exp. Pharmacol. 2005, 445-477. [CrossRef]

78. Lovell, M.E.; Bruno, R.; Johnston, J.; Matthews, A.; McGregor, I.; Allsop, D.J.; Lintzeris, N. Cognitive, physical, and mental health outcomes between long-term cannabis and tobacco users. Addict. Behav. 2018, 79, 178-188. [CrossRef]

79. Hall, W.; Degenhardt, L. Adverse health effects of non-medical cannabis use. Lancet 2009, 374, 1383-1391. [CrossRef]

80. Maule, W.J. Medical uses of marijuana (Cannabis sativa): Fact or fallacy? Br. J. Biomed. Sci. 2005, 72, 85-91. [CrossRef] [PubMed]

81. Blessing, E.M.; Steenkamp, M.M.; Manzanares, J.; Marmar, C.R. Cannabidiol as a potential treatment for anxiety disorders. Neurotherapeutics 2015, 12, 825-836. [CrossRef]

82. Patrick, M.E.; Terry-McElrath, Y.M.; Kloska, D.D.; Schulenberg, J.E. High-Intensity Drinking Among Young Adults in the United States: Prevalence, Frequency, and Developmental Change. Alcohol Clin. Exp. Res. 2016, 40, 1905-1912. [CrossRef]

83. Maurel, D.B.; Boisseau, N.; Benhamou, C.L.; Jaffre, C. Alcohol and bone: Review of dose effects and mechanisms. Osteoporos. Int. 2012, 23, 1-16. [CrossRef] [PubMed]

84. Skobic, I.; Apolinar, G.R.; Quan, S.F.; Haynes, P.L. Marijuana versus evidence-based treatments for sleep and relaxation: A cross-sectional study of use and dose modification following involuntary job loss. Sleep Health 2021, 7, 113-117. [CrossRef]

85. García-Marchena, N.; Barrera, M.; Mestre-Pintó, J.I.; Araos, P.; Serrano, A.; Pérez-Mañá, C.; Papaseit, E.; Fonseca, F.; Ruiz, J.J.; Rodríguez de Fonseca, F.; et al. Inflammatory mediators and dual depression: Potential biomarkers in plasma of primary and substance-induced major depression in cocaine and alcohol use disorders. PLoS ONE 2019, 14, e0213791. [CrossRef] [PubMed]

86. López, A.; Becoña, E. Depression and cocaine dependence. Psychol. Rep. 2007, 100, 520-524. [CrossRef]

87. Motschman, C.A.; Warner, O.M.; Wycoff, A.M.; Davis-Stober, C.P.; McCarthy, D.M. Context, Acute tolerance, and subjective response affect alcohol-impaired driving decisions. Psychopharmacology 2020, 237, 3603-3614. [CrossRef] [PubMed]

88. Neal, D.J.; Fromme, K. Event-level covariation of alcohol intoxication and behavioral risks during the first year of college. $J$. Consult. Clin. Psychol. 2007, 75, 294-306. [CrossRef] [PubMed]

89. Scott-Sheldon, L.A.; Carey, K.B.; Cunningham, K.; Johnso, B.T.; Carey, M.P.; Research Team MASH. Alcohol use predicts sexual decisionmaking: A systematic review and meta-analysis of the experimental literature. AIDS Behav. 2016, 20, 19-39. [CrossRef] [PubMed]

90. Elliott, M.R.; Shope, J.T.; Raghunathan, T.E.; Waller, P.F. Gender differences among young drivers in the association between high-risk driving and substance use/environmental influences. J. Stud. Alcohol 2006, 67, 252-260. [CrossRef]

91. Lonczak, H.S.; Neighbors, C.; Donovan, D.M. Predicting risky and angry driving as a function of gender. Accid. Anal. Prev. 2007, 39, 536-545. [CrossRef]

92. Ryb, G.E.; Dischinger, P.C.; Kufera, J.A.; Read, K.M. Risk perception and impulsivity: Association with risky behaviors and substance abuse disorders. Accid. Anal. Prev. 2006, 38, 567-573. [CrossRef]

93. Sewell, R.A.; Poling, J.; Sofuoglu, M. The effect of cannabis compared with alcohol on driving. Am. J. Addict. 2009, 18, 185-193. [CrossRef]

94. Spanish Observatory on Drugs and Addictions. Report 2021. Alcohol, Tobacco and Illegal Drugs in Spain; Ministry of Health, Government Delegation for the National Plan on Drugs: Madrid, Spain, 2021; pp. 30-113.

95. Lee, H.; Roh, S.; Kim, D.J. Alcohol-induced blackout. Int. J. Environ. Res. Public Health 2009, 6, 2783-2792. [CrossRef]

96. Caloca, S.; Fernández, A. Drug use in teenagers: Pattern of consumption and role of nursing in the prevention. Nuberos Cient. 2018, 3, 42-47.

97. Favrod-Coune, T.; Broers, B. The Health Effect of Psychostimulants: A Literature Review. Pharmaceuticals 2010, 3, $2333-2361$. [CrossRef] [PubMed]

98. Tirado-Muñoz, J.; Lopez-Rodriguez, A.B.; Fonseca, F.; Farré, M.; Torrens, M.; Viveros, M.P. Effects of cannabis exposure in the prenatal and adolescent periods: Preclinical and clinical studies in both sexes. Front. Neuroendocr. 2020, 57, 100841. [CrossRef] [PubMed] 
99. Raphael, B.; Wooding, S.; Stevens, G.; Connor, J. Comorbidity: Cannabis and complexity. J. Psychiatr. Pract. 2005, 11, 161-176. [CrossRef]

100. Patrick, M.E.; Bray, B.C.; Berglund, P.A. Reasons for marijuana use among young adults and long-term associations with marijuana use and problems. J. Stud. Alcohol Drugs 2016, 77, 881-888. [CrossRef]

101. Bachman, J.; Wadsworth, K.; O'Malley, P.; Johnston, L. Smoking, Drinking, and Drug Use in Young Adulthood: The Impacts of New Freedoms and New Responsibilities; Lawrence Erlbaum Associates, Inc.: Mahwah, NJ, USA, 1997; pp. 15-23.

102. Brook, J.S.; Brook, D.W.; Gordon, A.S.; Whiteman, M.; Cohen, P. The psychological etiology of adolescent drug use: A family interactional approach. Genet. Soc. Gen. Psychol. Monogr. 1990, 116, 111-267. [PubMed]

103. Nash, A.J.; Marcus, M.T.; Cron, S.; Scamp, N.; Truitt, M.; McKenna, Z. Preparing Nursing Students to Work with Patients with Alcohol or Drug-Related Problems. J. Addict. Nurs. 2017, 28, 124-130. [CrossRef]

104. Nevárez-Sida, A.; Carreón-Rodríguez, V.G.; Bergman, M. Socioeconomic Factors Associated with Drug Consumption in Mexico. J. Addict. Dis. 2021, 8, 1-9. [CrossRef]

105. Cantos Vicent, R. Men, Women and Drug Dependence. Social Explanation of Gender Differences in Problematic Drug Use; Athena Foundation: Athena, Spain, 2016; pp. 62-63.

106. Panevska, L.S.; Zafirova-Ivanovska, B.; Vasilevska, K.; Isjanovska, R.; Kadri, H. Relationship between ADHD and Depression among University Students in Macedonia. Mater. Sociomed. 2015, 27, 18-21. [CrossRef]

107. Bravo, A.J.; Pearson, M.R.; Pilatti, A.; Read, J.P.; Mezquita, L.; Ibáñez, M.I.; Ortet, G. Impulsivity-Related Traits, College Alcohol Beliefs, and Alcohol Outcomes: Examination of a Prospective Multiple Mediation Model among College Students in Spain, Argentina, and USA. Addict. Behav. 2018, 81, 125-133. [CrossRef]

108. Fugitt, J.L.; Ham, L.S.; Bridges, A.J. Undifferentiated Gender Role Orientation, Drinking Motives, and Increased Alcohol Use in Men and Women. Subst. Use Misuse 2017, 52, 760-772. [CrossRef] [PubMed]

109. De Salvia, M.A.; D'Uggento, A.M.; Aquilino, G.; Tattoli, M.; Finelli, C.; Imbrici, P.; Desaphy, J.F.; Giustino, A. Characterization of Student Drinking Behaviors at the Beginning of the First Academic Year at One University in Southern Italy. J. Addict. Nurs. 2019, 30, 193-200. [CrossRef]

110. Tsitsimpikou, C.; Tsarouhas, K.; Vasilaki, F.; Papalexis, P.; Dryllis, G.; Choursalas, A.; Spandidos, D.A.; Tsatsakis, A.; Charvalos, E.; Bacopoulou, F. Health risk behaviors among high school and university adolescent students. Exp. Ther. Med. 2018, 16, 3433-3438. [CrossRef]

111. Kandel, D.; Kandel, E. The Gateway Hypothesis of substance abuse: Developmental, biological and societal perspectives. Acta Paediatr. 2015, 4, 130-137. [CrossRef]

112. McKetin, R.; Coen, A.; Kaye, S. A comprehensive review of the effects of mixing caffeinated energy drinks with alcohol. Drug Alcohol Depend. 2015, 151, 15-30. [CrossRef]

113. Gruber, K.J.; Taylor, M.F. A family perspective for substance abuse: Implications from the literature. J. Soc. Work. Pract. Addict. 2006, 6, 1-29. [CrossRef]

114. Baca, C.T.; Yahne, C.E. Smoking cessation during substance abuse treatment: What you need to know. J. Subst. Abus. Treat. 2009, 36, 205-219. [CrossRef]

115. Wu, L.T.; Zhu, H.; Ghitza, U.E. Multicomorbidity of chronic diseases and substance use disorders and their association with hospitalization: Results from electronic health records data. Drug Alcohol Depend. 2018, 192, 316-323. [CrossRef]

116. Caldwell, T.M.; Rodgers, B.; Jorm, A.F.; Christensen, H.; Jacomb, P.A.; Korten, A.E.; Lynskey, M.T. Patterns of association between alcohol consumption and symptoms of depression and anxiety in young adults. Addiction 2002, 97, 583-594. [CrossRef] [PubMed]

117. Conway, K.P.; Compton, W.; Stinson, F.S.; Grant, B.F. Lifetime comorbidity of DSM-IV mood and anxiety disorders and specific drug use disorders: Results from the National Epidemiologic Survey on Alcohol and Related Conditions. J. Clin. Psychiatry 2006, 67, 247-257. [CrossRef] [PubMed]

118. Low, N.C.; Dugas, E.; O'Loughlin, E.; Rodriguez, D.; Contreras, G.; Chaiton, M.; O'Loughlin, J. Common stressful life events and difficulties are associated with mental health symptoms and substance use in young adolescents. BMC Psychiatry 2012, 12, 1-10. [CrossRef] [PubMed]

119. Creswell, K.G.; Chung, T.; Clark, D.B.; Martin, C.S. Solitary alcohol use in teens is associated with drinking in response to negative affect and predicts alcohol problems in young adulthood. Clin. Psychol. Sci. 2014, 2, 602-610. [CrossRef] [PubMed]

120. Creswell, K.G. Drinking together and drinking alone: A social-contextual framework for examining risk for alcohol use disorder. Curr. Dir. Psychol. Sci. 2021, 30, 19-25. [CrossRef]

121. Catalani, V.; Arillotta, D.; Corkery, J.M.; Guirguis, A.; Vento, A.; Schifano, F. Identifying New/Emerging Psychoactive Substances at the Time of COVID-19; A Web-Based Approach. Front. Psychiatry 2021, 11, 632405. [CrossRef]

122. Vanderbruggen, N.; Matthys, F.; Van Laere, S.; Zeeuws, D.; Santermans, L.; Van den Ameele, S.; Crunelle, C.L. Self-Reported Alcohol, Tobacco, and Cannabis Use during COVID-19 Lockdown Measures: Results from a Web-Based Survey. Eur. Addict. Res. 2020, 26, 309-315. [CrossRef] [PubMed]

123. Zaami, S.; Marinelli, E.; Varì, M.R. New Trends of Substance Abuse During COVID-19 Pandemic: An International Perspective. Front. Psychiatry 2020, 11, 700. [CrossRef] [PubMed]

124. Spanish Observatory of Drugs and Addictions. OEDA-COVID Survey: Impact of the COVID-19 Pandemic During 2020 on the Pattern of Use of Psychoactive Substances and Other Behaviors with Addictive Potential; Ministry of Health, Government Delegation for the National Plan on Drugs: Madrid, Spain, 2021; p. 42. 